\title{
PENINGKATAN KEMAMPUAN KOMUNIKASI MATEMATIK SISWA MENGGUNAKAN MODEL PEMBELAJARAN KOPERATIF
}

\author{
Fitriani $^{1}$, Wiwik Novitasari ${ }^{2}$ \\ ${ }^{1,}$ Program Studi Pendidikan Matematika, Fakultas Keguruan dan Ilmu Pendidikan \\ Universitas Muhammadiyah Tapanuli Selatan, Jl. Sutan Moh. Arief no. 32 Padangsidimpuan \\ ${ }^{1}$ fi3ani.hrp@gmail.com, ${ }^{2}$ vita.m.pd@gmail.com
}

\begin{abstract}
Communication skills focus on the importance of speaking, writing, describing and explaining mathematical concepts. In achieving that success is by using cooperative learning model. This model is an effective teaching strategy in improving student achievement and socialization while contributed to their changing of attitudes and perceptions of the importance of learning and cooperation, including for their understanding of their peers from different ethnic backgrounds. This research was conducted at SD IT Faza Azkia Kelurahan Hutaraja, South Tapanuli Regency, North Sumatera Province. This research uses quasi experimental research method. This study aims to describe how to improve students 'mathematical communication skills before and after using cooperative learning model, and also to know the effectiveness of using cooperative learning model in improving students' mathematical communication ability. Based on the results of the study concluded there is an increase in the mathematical communication skills of students before and after using cooperative learning model. And the cooperative learning model is effective for teaching count number operations. This is shown by: the effectiveness of student learning activities, the ability of teachers in managing learning is effective, students 'responses to learning is positive and mastery of students' mathematical communication skills reach 100\%.
\end{abstract}

Keywords: mathematical communication skill, cooperative learning model

\begin{abstract}
Abstrak. Kemampuan komunikasi berfokus pada pentingnya berbicara, menulis, menggambarkan dan menjelaskan konsep-konsep matematika. Dalam pencapain keberhasilan tersebut ialah dengan menggunakan model pembelajaran koperatif. Model ini merupakan strategi pengajaran efektif dalam meningkatkan prestasi dan sosialisasi siswa sekaligus turut berkontribusi bagi perbaikan sikap dan persepsi mereka tentang pentingnya belajar dan bekerja sama, termasuk bagi pemahaman mereka tentang temantemannya yang berasal dari latar belakang etnis yang berbeda-beda. Penelitian ini dilakukan di SD IT Faza Azkia Kelurahan Hutaraja Kabupaten Tapanuli Selatan Provinsi Sumatera Utara. Penelitian ini menggunakan metode penelitian kuasi eksperimen. Penelitian ini bertujuan untuk mendeskripsikan bagaimana peningkatan kemampuan komunikasi matematik siswa sebelum dan sesudah menggunakan model pembelajaran koperatif, dan juga untuk mengetahui efektivitas penggunaan model pembelajaran koperatif dalam meningkatkan kemampuan komunikasi matematik siswa. Berdasarkan hasil penelitian disimpulkan terdapat peningkatan kemampuan komunikasi matematik siswa sebelum dan sesudah menggunakan model pembelajaran koperatif. Dan model pembelajaran koperatif efektif untuk mengajarkan operasi hitung bilangan. Hal ini ditunjukkan oleh: efektivitas aktivitas belajar siswa, kemampuan guru dalam mengelola pembelajaran adalah efektif, respon siswa terhadap pembelajaran adalah positif dan ketuntasan kemampuan komunikasi matematik siswa mencapai $100 \%$.
\end{abstract}

Kata Kunci: kemampuan komunikasi matematik, model pembelajaran koperatif

\section{PENDAHULUAN}

Menurut Dimyati dan Mudjiono (2006) belajar merupakan peristiwa sehari-hari di sekolah. Belajar merupakan hal yang kompleks. Kompleksitas tersebut dapat dipandang dari dua subjek, yaitu dari siswa dan guru. Dari segi siswa belajar dialami 
sebagai suatu proses, sedangkan dari segi guru proses belajar tersebut tampak sebagai perilaku belajar tentang sesuatu hal. Kemampuan yang harus dicapai dalam pembelajaran matematika yaitu meliputi: (1) kemampuan pemecahan masalah, (2) kemampuan komunikasi, (3) kemampuan koneksi, (4) kemampuan penalaran, dan (5) kemampuan refresentasi. Salah satu dari lima kemampuan matematik yang harus dicapai yaitu kemampuan komunikasi. Menurut Abdulhak (Ansari, 2009), komunikasi dimaknai sebagai proses penyampaian pesan dari pengirim pesan kepada penerima pesan melalui saluran tertentu untuk tujuan tertentu. Standar komunikasi menitik beratkan pada pentingnya dapat berbicara, menulis, menggambarkan dan menjelaskan konsep-konsep matematika.

Baroody (Ansari, 2009) menyebutkan sedikitnya ada dua alasan penting, mengapa komunikasi dalam pembelajaran matematika perlu ditumbuh kembangkan dikalangan siswa, yaitu matematika tidak hanya sekedar alat bantu berpikir, alat bantu menemukan pula, menyelesaikan masalah atau mengambil kesimpulan, tetapi matematika juga sebagai aktivitas sosial dalam pembelajaran matematika, matematika sebagai wahana interaksi antar siswa, dan juga antar guru dan siswa. Agar pencapaian kemampuan matematik tersebut sesuai dengan yang diharapkan, maka seorang guru harus memperhatikan dan mempertimbangkan model perencanaan pembelajaran yang akan dilaksanakan. Dalam hal ini, guru harus menarik minat siswa agar lebih tertarik mengikuti pembelajaran yang kita inginkan. Sehingga minat belajar siswa makin meningkat dan bergairah mengikuti pembelajaran.

Namun kenyataannya dilapangan berdasarkan observasi peneliti terhadap beberapa sekolah SD, pendidikan yang ada saat ini merupakan pendidikam tradisional. Menurut Ruseffendi (1991) pengajaran tradisional ialah pengajaran pada umumnya yang biasa kita lakukan sehari-hari, "pendidikan tradisional dengan "sekolah dengar"nya tidak mengenal bahkan sama sekali tidak menggunakan asas aktivitas dalam proses belajar mengajar". Para siswa hanya mendengarkan hal-hal yang disampaikan oleh guru. Padahal pada hakikatnya, proses pendidikan bertujuan untuk membentuk manusia yang cerdas, memiliki kemampuan memecahkan masalah hidup serta diarahkan untuk membentuk manusia yang kreatif dan inovatif.

Maka penulis memberikan solusi dari masalah tersebut dengan memilih salah satu model pembelajaran yang dapat meningkatkan kemampuan komunikasi matematik siswa yaitu model pembelajaran koperatif. Adapun alasan peneliti tertarik memilih menggunakan model pembelajaran koperatif yaitu didasari pendapat Johnson, dkk, Johnson dan Johnson, Slavin, dan Sharan (Huda, 2011) menunjukkan bahwa model pembelajaran koperatif merupakan strategi pengajaran efektif dalam meningkatkan prestasi dan sosialisasi siswa sekaligus turut berkontribusi bagi perbaikan sikap dan persepsi mereka tentang begitu pentingnya belajar dan bekerja sama, termasuk bagi pemahaman mereka tentang teman-temannya yang berasal dari latar belakang etnis yang berbeda-beda.

Mengingat begitu pentingnya meningkatkan kemampuan matematik siswa dalam upaya menghadapi berbagai masalah dalam kehidupannya, maka penulis ingin memberikan sumbangan pemikiran dalam hal kegiatan penelitian, dengan memilih judul penelitian: "Peningkatan Kemampuan Komunikasi Matematik Siswa Menggunakan Model Pembelajaran Koperatif”. 


\section{METODE}

Jenis penelitian adalah kuasi eksperimen. Rancangan yang digunakan dalam penelitian meliputi empat tahap, yaitu: (1) Tahap penyusunan instrument penelitian, (2) Tahap Validasi instrument (3) tahap uji coba instrument, dan (4) Tahap pelaksanaan eksperimen. Teknik pengumpulan data yang digunakan untuk memperoleh data dalam penelitian ini adalah tes kemampuan komunikasi matematik yang berbentuk essay test, dan lembar pengamatan yang terdiri dari lembar pengamatan aktivitas siswa, lembar pengamatan kemampuan guru mengelola pembelajaran, dan angket respon siswa. Analisis data dilakukan dengan menggunakan statistik deskriptif dan statistik kuantitatif.

\section{HASIL DAN PEMBAHASAN}

Penelitian ini dilaksanakan 4 kali pertemuan, sesuai dengan rencana pembelajaran yang telah dibuat, serta 2 kali pertemuan untuk pre tes dan pos tes. Kelas penelitian adalah kelas III-A sebagai kelas kontrol dan III-B sebagai kelas eksperimen SD IT Faza Azkia. Pada kegiatan ini peneliti juga bertindak sebagai guru dalam menerapkan model pembelajaran koperatif yang telah dibuat.

Pelaksanaan penelitian ini diikuti oleh 2 orang pengamat yang mempunyai tugas yang berbeda. Satu pengamat mengamati aktivitas kegiatan siswa dan satu pengamat lagi untuk mengamati kemampuan guru mengelola pembelajaran. Dalam proses pembelajaran, siswa dikelompokkan menjadi 4-5 orang satu kelompok, yang terdiri dari 1 orang siswa kelompok atas, 2 orang siswa kelompok tengah, dan 1-2 orang siswa kelompok bawah. Pengelompokan siswa atas, tengah dan bawah berdasarkan nilai semester genap kelas II dan wawancara atau konsultasi dengan guru matematika yang bersangkutan. Dengan demikian dapat dikatakan bahwa rata-rata kemampuan siswa setiap kelompoknya adalah relatif sama. Berikut adalah akan dijelaskan secara rinci hasil yang sudah diperoleh selama kegiatan penelitian.

\section{Hasil Kemampuan Komunikasi Matematik}

Untuk melihat bagaimana peningkatan kemampuan komunikasi matematik siswa sebelum dan sesudah menggunakan model pembelajaran koperatif dianalisis dengan menggunakan bantuan Statistik SPSS dengan hipotesis penelitian:

$\mathrm{H}_{0}$ : Tidak Ada peningkatan kemampuan komunikasi matematik siswa sebelum dan sesudah menggunakan model pembelajaran koperatif

$\mathrm{H}_{\mathrm{a}}$ : Ada peningkatan kemampuan komunikasi matematik siswa sebelum dan sesudah menggunakan model pembelajaran koperatif

Dengan bantuan SPSS diperoleh Output perhitungan seperti pada tabel 1 berikut:

Tabel 1. Paired Samples Test

\begin{tabular}{|c|c|c|c|c|c|c|c|c|c|}
\hline & & \multicolumn{5}{|c|}{ Paired Differences } & \multirow[t]{3}{*}{$t$} & \multirow[t]{3}{*}{$d f$} & \multirow{3}{*}{$\begin{array}{l}\text { Sig. (2- } \\
\text { tailed) }\end{array}$} \\
\hline & & \multirow[t]{2}{*}{ Mean } & \multirow[t]{2}{*}{$\begin{array}{c}\text { Std. } \\
\text { Deviation }\end{array}$} & \multirow[t]{2}{*}{$\begin{array}{l}\text { Std. Error } \\
\text { Mean }\end{array}$} & \multicolumn{2}{|c|}{$\begin{array}{l}95 \% \text { Confidence } \\
\text { Interval of the } \\
\text { Difference }\end{array}$} & & & \\
\hline & & & & & Lower & Upper & & & \\
\hline Pair 1 & $\begin{array}{l}\text { sebelum - } \\
\text { sesudah }\end{array}$ & $-15,524$ & 2,994 & ,653 & $-16,886$ & $-14,161$ & $-23,763$ & 20 & ,000 \\
\hline
\end{tabular}

Berdasarkan tabel di atas dapat dilihat bahwa nilai signifikan yang digunakan SPSS adalah 0,05 dan $\mathrm{df}=20$ maka dengan menggunakan uji 2 sisi pada tabel $\mathrm{t}$ didapat 
nilai $t_{\text {tabel }}=2,086$ sedangkan nilai $t_{\text {hitung }}=-23,763$, dimana nilai $t_{\text {hitung }}$ terletak di luar range $-2,068$ dan $+2,068$. Tanpa melihat nilai negatif maka diperoleh $t_{\text {hitung }}>t_{\text {tabel }}$ yaitu 23,763 $>$ 2,021 maka $\mathrm{H}_{0}$ ditolak dan terima $\mathrm{H}_{\mathrm{a}}$. Artinya Ada peningkatan kemampuan komunikasi matematik siswa sebelum dan sesudah menggunakan model pembelajaran koperatif.

Berdasarkan kriteria ketuntasan belajar (KKM) mata pelajaran matematika di kelas III sebesar 70, maka terhadap tes kemampuan komunikasi matematik siswa dibandingkan dengan sebelum dan sesudah diberikan perlakuan berupa model pembelajaran koperatif terdapat 0 siswa $(0 \%)$ yang tidak lulus pada saat sebelum diberikan perlakuan yaitu dengan pemberian pre tes dan terdapat 21 siswa (100\%) yang lulus sesudah diberikan perlakuan. Persentase ketuntasan siswa sesudah diberikan perlakuan mencapai persentase maksimal. Hasil tersebut menunjukkan bahwa dengan menggunakan model pembelajaran koperatif dapat meningkatkan kemampuan komunikasi matematik siswa sehingga dapat meningkatkan jumlah siswa yang tuntas belajar.

\section{Hasil Pengamatan Aktivitas Siswa Selama Pembelajaran}

Tabel 2. Persentase Aktivitas Siswa Selama Pembelajaran

\begin{tabular}{|c|c|c|c|c|c|c|}
\hline \multirow[t]{2}{*}{ No } & \multirow[t]{2}{*}{ Kategori Pengamatan } & \multicolumn{4}{|c|}{$\begin{array}{c}\text { Persentase Aktivitas Siswa dalam } \\
\text { Pembelajaran }\end{array}$} & \multirow{2}{*}{$\begin{array}{c}\text { Kriteria } \\
\text { Batasan } \\
\text { Keaktifan } \\
\quad(\%)\end{array}$} \\
\hline & & RPP I & RPP II & RPP III & RPP IV & \\
\hline 1 & $\begin{array}{l}\text { Memperhatikan/mendengarkan } \\
\text { penjelasan guru/teman dengan } \\
\text { aktif }\end{array}$ & 16,667 & 16,667 & 18,452 & 14,881 & $9-19$ \\
\hline 2 & $\begin{array}{l}\text { Membaca/memahami masalah } \\
\text { kontekstual pada LAS siswa }\end{array}$ & 14,286 & 14,881 & 14,881 & 13,690 & $6-16$ \\
\hline 3 & $\begin{array}{l}\text { Menyelesaikan } \\
\text { masalah/menemukan jawaban dan } \\
\text { cara untuk menjawab masalah } \\
\text { kontekstual }\end{array}$ & 22,619 & 26,786 & 26,786 & 27,381 & $33-34$ \\
\hline 4 & $\begin{array}{l}\text { Berdiskusi/bertanya antara siswa } \\
\text { dan guru }\end{array}$ & 24,405 & 21,429 & 22,619 & 25,595 & $19-29$ \\
\hline 5 & $\begin{array}{l}\text { Menarik kesimpulan suatu } \\
\text { prosedur/konsep }\end{array}$ & 16,667 & 16,667 & 14,881 & 16,667 & $8-18$ \\
\hline 6 & $\begin{array}{l}\text { Perilaku yang tidak relevan } \\
\text { dengan KBM }\end{array}$ & 5,357 & 3,571 & 2,381 & 1,786 & $0-5$ \\
\hline
\end{tabular}

Dari tabel 2 di atas, dapat dianalisis bahwa rata-rata aktivitas siswa berada pada kriteria batasan keefektifan pembelajaran, kecuali pada pertemuan pertama (RPP I) terdapat persentase aktivitas siswa yang bedara di atas kriteria batasan keaktifan yaitu Perilaku yang tidak relevan dengan KBM (Kegiatan belajar Mengajar). Hal ini dapat dimaklumi karena guru dan siswa masih menyesuaikan diri dengan model pembelajaran yang diterapkan dan masih terpengaruh pada pembelajaran biasa. Sehingga aktivitas siswa masih banyak Perilaku yang tidak relevan dengan KBM dimana semua siswa merasa ingin diperhatikan. Untuk mengantisipasinya, pada pertemuan kedua lebih banyak memotivasi siswa supaya lebih aktif dalam mengikuti proses pembelajaran. Hal ini diharapkan pada pertemuan-pertemuan berikutnya aspekaspek yang ditentukan berada pada batas keefektifan pembelajaran. Karena pada umumnya persentase aktivitas siswa berada pada kriteria batasan keefektifan pembelajaran, maka perangkat pembelajaran tidak mengalami revisi berdasarkan hasil pengamatan aktivitas siswa. 
3. Hasil Penilaian Kemampuan Guru Mengelola Pembelajaran

Tabel 3. Kemampuan Guru Mengelola Pembelajaran

\begin{tabular}{|c|c|c|c|c|c|c|c|}
\hline \multirow[b]{2}{*}{ No } & \multirow{2}{*}{$\begin{array}{c}\text { Kegiatan/Aspek yang } \\
\text { Diamati }\end{array}$} & RPP I & RPP II & RPP III & RPP IV & Rata- & \multirow{2}{*}{$\begin{array}{c}\text { Nilai } \\
\text { Kategori }\end{array}$} \\
\hline & & $\begin{array}{l}\text { Rata- } \\
\text { rata }\end{array}$ & $\begin{array}{c}\text { Rata- } \\
\text { rata }\end{array}$ & $\begin{array}{l}\text { Rata- } \\
\text { rata }\end{array}$ & $\begin{array}{l}\text { Rata- } \\
\text { rata }\end{array}$ & Rata & \\
\hline 1 & Pendahuluan terdiri dari & & & & & & 4,0625 \\
\hline & $\begin{array}{l}\text { 1) Menyampaikan } \\
\text { tujuan pembelajaran }\end{array}$ & 3,5 & 4 & 4 & 4 & 3,875 & \\
\hline & 2) Memotivasi siswa. & 4 & 4,5 & 4 & 4,5 & 4,25 & \\
\hline 2 & Kegiatan inti terdiri dari & & & & & & 4,325 \\
\hline & $\begin{array}{l}\text { 1) Menyajikan } \\
\text { informasi }\end{array}$ & 4 & 3,5 & 3,5 & 4,5 & 3,875 & \\
\hline & $\begin{array}{l}\text { 2) Mengorganisasikan } \\
\text { ke dalam kelompok- } \\
\text { kelompok belajar }\end{array}$ & 3,5 & 5 & 5 & 5 & 4,625 & \\
\hline & $\begin{array}{l}\text { 3) } \begin{array}{l}\text { Membimbing } \\
\text { kelompok bekerja } \\
\text { dan belajar }\end{array}\end{array}$ & 3,5 & 5 & 5 & 5 & 4,625 & \\
\hline & 4) Memberikan evaluasi & 4 & 4,5 & 4 & 4 & 4,125 & \\
\hline & $\begin{array}{l}\text { 5) } \begin{array}{l}\text { Memberikan } \\
\text { penghargaan }\end{array} \\
\end{array}$ & 4 & 4 & 5 & 4,5 & 4,375 & \\
\hline 3 & Penutup terdiri dari & & & & & & 3,625 \\
\hline & $\begin{array}{l}\text { 1) Menegaskan kembali } \\
\text { kesimpulan materi }\end{array}$ & 3 & 4 & 4 & 4 & 3,75 & \\
\hline & $\begin{array}{l}\text { 2) Memberi beberapa } \\
\text { soal sebagai tugas } \\
\text { mandiri. }\end{array}$ & 3,5 & 3,5 & 3,5 & 3,5 & 3,5 & \\
\hline 4 & $\begin{array}{l}\text { Pengelolaan waktu } \\
\text { pembelajaran }\end{array}$ & 3 & 4 & 4 & 4 & 3,75 & 3,75 \\
\hline 5 & $\begin{array}{l}\text { Suasana di kelas terdiri } \\
\text { dari }\end{array}$ & & & & & & 4,5625 \\
\hline & $\begin{array}{ll}\text { 1) Antusias siswa } \\
\text { mengikuti } \\
\text { pembelajaran }\end{array}$ & 4 & 4,5 & 5 & 5 & 4,625 & \\
\hline & $\begin{array}{lll}\text { 2) } & \text { Antusias guru } \\
\text { mengelola } & \\
\text { pembelajaran. } & \end{array}$ & 4 & 4,5 & 5 & 4,5 & 4,5 & \\
\hline & Jumlah & 44 & 51 & 52 & 52,5 & 49,875 & 20,325 \\
\hline & Rata-Rata & 3,667 & 4,25 & 4,333 & 4,375 & 4,156 & 4,065 \\
\hline
\end{tabular}

Berdasarkan tabel 3 dapat dianalisis bahwa, kemampuan guru mengelola pembelajaran pada setiap pertemuan mencapai kategori "Baik". Jika dilihat pada setiap aspek maka kemampuan guru masih ada yang berada pada kategori "cukup baik" (nilai 3). Ini dapat terlihat pada: kegiatan penutupan pada poin menegaskan kembali kesimpulan materi dan berapa pada pengelolaan waktu pembelajaran. Penilaian cukup baik ini ditemukan pada pertemuan pertama (RPP I), karena peneliti dan siswa masih belum terbiasa dimana peneliti dan siswa juga mengalami kesulitan, bagi siswa kesulitan memahami masalah kontekstual yang diberikan, sedangkan bagi peneliti kesulitannya ialah ketika menghadapi berbagai banyak pertanyaan siswa dalam memahami masalah kontekstual serta kesulitan mengarahkan siswa untuk bekerja secara berkelompok. Untuk mengatasi hal ini supaya tidak terjadi lagi pada 
pertemuan berikutnya peneliti lebih banyak memotivasi dan menjelaskan manfaat ketika proses pembelajaran diikuti dengan aktif. Sehingga untuk pertemuan berikutnya dapat berjalan sesuai dengan yang diinginkan. Berdasarkan kriteria, disebabkan kemampuan guru mengelola pembelajaran sudah mencapai kategori "baik", maka perangkat pembelajaran tidak mengalami revisi berdasarkan hasil pengamatan terhadap kemampuan guru mengelola pembelajaran.

\section{Hasil Angket Respon Siswa}

Dari angket respon siswa yang diberikan kepada 21 siswa setelah mengikuti pembelajaran dengan menggunakan perangkat pembelajaran melalui model pembelajaran koperatif untuk topik bahasan operasi hitung bilangan, maka diperoleh hasil dengan rincian seperti tabel 4 berikut ini.

Tabel 4. Hasil Angket Respon Siswa Terhadap Perangkat dan Pelaksanaan Model Pembelajaran Kooperatif

\begin{tabular}{|c|c|c|c|c|c|}
\hline \multirow[t]{2}{*}{ No } & \multirow[t]{2}{*}{ Aspek yang Diamati } & \multicolumn{2}{|c|}{ Respon Siswa } & \multicolumn{2}{|c|}{ Persentase } \\
\hline & & Senang & $\begin{array}{c}\text { Tidak } \\
\text { Senang }\end{array}$ & Senang & $\begin{array}{c}\text { Tidak } \\
\text { Senang }\end{array}$ \\
\hline 1 & $\begin{array}{l}\text { Bagaimana perasaanmu } \\
\text { terhadap komponen }\end{array}$ & & & & \\
\hline & a. Materi Pelajaran & 19 & 2 & 90,476 & 9,524 \\
\hline & $\begin{array}{l}\text { b. Lembar Aktivitas Siswa } \\
\text { (LAS) }\end{array}$ & 19 & 2 & 90,476 & 9,524 \\
\hline & c. Suasana Belajar di Kelas & 20 & 1 & 95,238 & 4,762 \\
\hline & d. Cara Guru Mengajar & 20 & 1 & 95,238 & 4,762 \\
\hline & & Baru & $\begin{array}{l}\text { Tidak } \\
\text { Baru }\end{array}$ & Baru & Tidak Baru \\
\hline
\end{tabular}

2 Bagaimana perasaanmu terhadap komponen?

\begin{tabular}{|c|c|c|c|c|c|}
\hline & a. Materi Pelajaran & 20 & 1 & 95,238 & 4,762 \\
\hline & $\begin{array}{lll}\text { b. } \begin{array}{l}\text { Lembar Aktivitas Siswa } \\
\text { (LAS) }\end{array} & \\
\end{array}$ & 21 & 0 & 100 & 0 \\
\hline & c. Suasana Belajar di Kelas & 21 & 0 & 100 & 0 \\
\hline & d. Cara Guru Mengajar & 20 & 1 & 95,238 & 4,762 \\
\hline & & Berminat & $\begin{array}{c}\text { Tidak } \\
\text { Berminat }\end{array}$ & Berminat & $\begin{array}{c}\text { Tidak } \\
\text { Berminat }\end{array}$ \\
\hline \multirow[t]{2}{*}{3} & $\begin{array}{l}\text { Apakah kamu berminat } \\
\text { mengikuti kegiatan belajar } \\
\text { selanjutnya seperti yang telah } \\
\text { kamu ikuti sekarang ini? }\end{array}$ & 20 & 1 & 95,238 & 4,762 \\
\hline & & $\mathrm{Ya}$ & Tidak & $\mathrm{Ya}$ & Tidak \\
\hline 4 & $\begin{array}{l}\text { Bagaimana pendapatmu tentang } \\
\text { buku siswa dan Lembar } \\
\text { Aktivitas Siswa (LAS)? }\end{array}$ & & & & \\
\hline & $\begin{array}{lll}\text { a. Apakah } & \text { kamu } & \text { dapat } \\
\text { memahami } & \text { bahasa } & \text { yang } \\
\text { digunakan } & \text { dalam } & \text { buku } \\
\text { siswa/LAS? } & & \end{array}$ & 20 & 1 & 95,238 & 4,762 \\
\hline
\end{tabular}



b. Apakah kamu tertarik pada penampilan (tulisan, ilustrasi, gambar, dan letak gambarnya) yang terdapat pada buku siswa/LAS?

Dari tabel 4 dapat dianalisis bahwa respon siswa terhadap semua aspek terutama terhadap perangkat pembelajaran yaitu pendapat siswa terhadap komponen pembelajaran yang terdiri dari lembar aktivitas siswa (LAS), dan tes kemampuan komunikasi matematik berada di atas $90 \%$. Artinya setiap aspek direspon positif oleh siswa sehingga perangkat pembelajaran tidak mengalami revisi berdasarkan respon siswa.

Jadi, dari semua hasil perhitungan yang diperoleh tersebut menunjukkan bahwa dengan menggunakan model pembelajaran koperatif dapat meningkatkan kemampuan komunikasi matematik siswa di SD Kelas III dan model pembelajaran koperatif efektif untuk mengajarkan operasi hitung bilangan.

\section{KESIMPULAN DAN SARAN \\ Kesimpulan}

Dari penelitian yang telah dilakukan dan berdasarkan analisis yang dilakukan maka diperoleh kesimpulan bahwa

1. Ada peningkatan kemampuan komunikasi matematik siswa sebelum dan sesudah menggunakan model pembelajaran koperatif

2. Model pembelajaran koperatif efektif untuk mengajarkan operasi hitung bilangan. Hal ini ditunjukkan oleh:
a) Aktivitas siswa: efektif
b) Kemampuan guru mengelola pembelajaran: efektif
c) Respon siswa terhadap pembelajaran: positif
d) Ketuntasan kemampuan komunikasi matematik 100\% siswa mencapai KKM hal ini menunjukkan terjadi peningkatan kemampuan komunikasi matematik siswa yang diajar dengan menggunakan model pembelajaran koperatif.

\section{Saran}

Berdasarkan hasil penelitian ini, model pembelajaran koperatif pada kegiatan pembelajaran memberikan beberapa hal yang penting untuk diperhatikan. Untuk itu peneliti menyarankan beberapa hal:

1. Bagi guru yang ingin mengajarkan materi operasi hitung bilangan sudah efektif menggunakan model pembelajaran koperatif

2. Bagi guru yang ingin meningkatkan kemampuan komunikasi matematik sangat sesuai menggunakan model pembelajaran koperatif

3. Bagi guru-guru yang ingin mengajar ditingkat SD sangat cocok menerapkan model pembelajaran koperatif karena siswa merasa sangat senang mengikuti proses pembelajaran dengan koperatif, selain itu juga rasa tanggung jawab pada anak semakin terlatih dan juga saling menghargai antara siswa semakin terbangun.

\section{UCAPAN TERIMAKASIH}

Pada kesempatan ini peneliti mengucapkan terima kasih kepada: Direktorat Riset dan Pengabdian Masyarakat Direktorat Jenderal Penguatan Riset dan Pengembangan Kementerian Riset, Teknologi, dan Pendidikan Tinggi yang telah 
memeberikan bantuan dana, Universitas Muhammadiyah Tapanuli Selatan, LPPM Universitas Muhammadiyah Tapanuli Selatan dan SD IT Faza Azkia Kel. Hutaraja Kec. Muara Batang Toru Kab. Tapanuli Selatan.

\section{DAFTAR PUSTAKA}

Ansari, I. 2009. Komunikasi Matematika. Jakarta: Pena.

Arikunto, S. 2012. Dasar-dasar Evaluasi Pendidikan (Edisi 2). Jakarta: Bumi Aksara. Dimyati dan Mudjiono. 2006. Belajar dan Pembelajaran. Jakarta: PT Rineka Cipta

Huda, M. 2011. Cooperative Learning Metode, Teknik, Struktur dan Model Penerapan. Yogyakarta: Pustaka Pelajar.

Russefendi, E. T. 1991. Pengantar kepada Membantu Guru Mengembangkan Kompetensinya dalam Pengajaran Matematika Untuk Meningkatkan CBSA. Bandung: Tarsito. 